\title{
ANALISIS REDUPLIKASI KATA KERJA DALAM KALIMAT BAHASA MANDARIN
}

\author{
Niza A yuningtias \\ Program Studi Sastra Cina Fakultas IImu Budaya \\ Universitas Sumatera Utara \\ Pos-el: niza.ayuningtias@yahoo.com
}

\begin{abstract}
A bstrak
M orfologi adalah bagian linguistik yang mempelajari morfem serta menganalisis struktur, bentuk, dan klasifikasi kata-kata. A da duajenismorfem, yaitu morfem bebas dan morfem terikat. M orfem bebas secara morfemis adalah morfem yang dapat berdiri sendiri, sedangkan morfem terikat adalah morfem yang tidak bisa berdiri sendiri dan membutuhkan morfem lainnya. Proses morfemis salah satu di antaranya adalah proses reduplikasi. Reduplikasi yang dibahas dalam penelitian ini adalah reduplikasi kata kerja. Tujuan dari penelitian ini adalah untuk mendeskripsikan jenis-jenis dan pola-pola reduplikasi morfemis dalam kalimat bahasa Mandarin. Teori yang digunakan dalam penelitian adalah teori morfologi struktural oleh Ramlan sebagai alat untuk menganalisis data yang ada. Metode yang digunakan dalam penelitian ini adalah metode penelitian kualitatif yang bersifat deskriptif dengan memaparkan jenis-jenis dan pola-pola reduplikasi morfemis bahasa M andarin. Berdasarkan hasil analisis dapat diketahui bahwa pada reduplikasi kata kerja terdapat pengulangan seluruh dan ada juga yang mengalami pengulangan yang berkombinasi dengan afiks. Pola reduplikasi kata kerja yaitu pengulangan kata kerja monosilabel memiliki pola AA, pengulangan katakerja berinfiks memiliki polaANA dan pengulangan katakerja dislabik memiliki polaABAB
\end{abstract}

Kata kunci : morfologi, morfem, reduplikasi katakerja

\begin{abstract}
M orphology is part of linguistic study about morphemeand analysing structureand classification of words. There are two kinds of morphemes. They are free morpheme and bound morpheme. Free morpheme is a morphemethat can stand aloneas a word. Whilebound morphemeis a morphemethat cannot stand al oneas a word or needs other morphemes. The process discussing about words in morphology is called morphemic process or morphology process. Reduplication is a kind of morphemic process. There are one reduplications (reduplication of verb) discussed in this research. The purpose of this research is to describe patterns of morphemic reduplication in $\mathrm{M}$ andarin sentences. Thetheory used in this research is structural morphology theory from Ramlan an instrument to analyzethe data. Structural mor phology is a kind of linguistics discuss about thestructure and the process of word formation. Themethod used in this research is qual itative research method which describes about structures and patterns of morphemic reduplication in $M$ andarin. Based on the results of the analysis can beseen that thereduplication of verbs ther eis repetition of the whol eand thereis also a repetition in combination with affix. The pattern of verb reduplication is the repetition of the monosilabel verb has $A A$ pattern, the repetition of infected verbs has $A N A$ pattern and therepetition of theverbs dislabik has an $A B A B$ pattern
\end{abstract}

Keywords : morphology, morpheme, reduplication of verb

\section{PEN DAHULUAN}

Bahasa adalah kunci pokok bagi kehidupan manusia sebagai makhluk sosial, karena dengan bahasa kita bisa berkomunikasi satu de- ngan yang lain. Bahasa merupakan lambang bunyi antar anggota masyarakat, berupa simbol bunyi yang dihasilkan oleh alat ucap manusia. Melalui bahasa, seseorang dapat berinteraksi 
atau berhubungan dengan orang lain dalam memenuhi segala kebutuhan. Komunikasi dapat dilakukan dengan berbagai cara yang sifatnya komunikatif, artinya seorang sebagai pemberi informasi dan orang lain sebagai penerima informasi (Keraf, 2001:1).

Bentuk bahasa yang digunakan dapat berbentuk lisan maupun berbentuk tulisan. Pada bahasa lisan, suatu ide, pikiran atau keinginan disampaikan secara langsung dengan cara diucapkan dan dengan bantuan udara pernafasan. Sedangkan bahasa tulis merupakan bahasa yang ditulis dengan menggunakan sistem tulisan.

Salah satu bahasa yang mulai menunjukkan keberadaan dan peranannya di dunia adalah bahasa Mandarin. Bahasa Mandarin adalah bahasa nasional rakyat Tiongkok yang saat ini telah menjadi bahasa internasional. Saat ini bahasa Mandarin sudah menjadi salah satu bahasa yang dianggap penting di dunia seiring dengan perkembangan perekonomian dunia. Di Indonesia penggunaan bahasa Mandarin menjadi hal yang sangat penting, bahasa Mandarin kini dipelajari hampir di seluruh dunia khususnya di Indonesia. Bahkan bahasa Mandarin telah diajarkan di sekolahsekolah baik negeri maupun swasta, terutama di kota-kota besar di Indonesia. Fenomena ini menunjukkan bahwa bahasa Mandarin me miliki daya tarik tersendiri bagi peminatnya. Jika seseorang dapat berkomunikasi dalam bahasa Mandarin berarti orang tersebut juga harus menguasai secara baik tata bahasanya.

Tata bahasa adalah kaidah atau aturanaturan yang telah tersistem dalam menyusun kata, gabungan kata, dan kalimat. Tanpa menggunakan tata bahasa yang tepat, makna/ informasi suatu kalimat tidak dapat diutarakan dengan baik dan benar sehingga komunikasi tidak dapat berlangsung dengan baik. Menurut Yongxin (2005:1), tata bahasa merupakan suatu kaidah pembentukan kalimat dengan kata yang ada. Tanpa adanya tata bahasa, tidak akan muncul bahasa. $\mathrm{Hal}$ ini berarti bahwa tata bahasa sangat penting pada kegiatan berbahasa dalam bahasa tersebut. Tata bahasa yang terdapat dalam bahasa Mandarin sangat banyak yang meliputi morfem, kata, gabungan kata, dan kalimat. M orfem merupakan bagian terkecil dari morfologi.

Ramlan, (1965: 6) menyatakan bahwa morfologi adalah bagian dari ilmu yang membicarakan seluk-beluk bentuk kata, pengaruh perubahan-perubahan bentuk kata terhadap golongan dan arti kata. Sedangkan menurut Verhaar (2008: 97) morfologi adalah cabang linguistik yang mengidentifikasikan satuansatuan dasar bahasa sebagai satuan gramatikal. Morfologi adalah bagian linguistik yang mempelajari morfem serta menganalisis struktur, bentuk, dan klasifikasi kata-kata. A da dua jenis morfem, yaitu morfem bebas dan morfem terikat. M orfem bebas secara morfemis adalah morfem yang dapat berdiri sendiri, sedangkan morfem terikat adalah morfem yang tidak bisa berdiri sendiri dan membutuhkan morfem lainnya. Morfologi membahas mengenai selukbeluk kata. Proses yang membicarakan kata dalam morfologi disebut dengan proses morfemis atau proses morfologis. Proses morfemis yaitu proses afiksasi, proses reduplikasi, proses komposisi, proses konversi, dan proses modifikasi intern.

Ramlan (1965:38) mengatakan kata ulang atau reduplikasi adalah proses pengulangan satuan gramatik baik seluruhnya atau sebagian, baik dengan variasi fonem maupun tidak. Hasil pengulangan itu disebut kata ulang, sedangkan satuan yang diulang merupakan bentuk dasarnya. Reduplikasi atau kata ulang adalah proses pengulangan kata, baik secara utuh maupun secara sebahagian, baik bervariasi fonem maupun tidak, baik berkombinasi dengan afiks maupun tidak asar tanpa afiks, yaitu: rumah menjadi rumah-rumah. Reduplikasi seluruh bentuk dasar dengan afiks, yaitu: reduplikasi prefiks \{me-\}pada kata "nari" menjadi kata "menari-nari", reduplikasi dengan simulfiks \{me+kan\}padakata “lambai" menjadi 
kata "melambai-lambaikan", reduplikasi dengan sufiks \{an\} pada kata "rumah" menjadi kata "rumah-rumahan" dan reduplikasi dengan infiks \{-em\} pada kata "guruh" menjadi kata "guruh-gemuruh".

Pada bahasa Mandarin juga terdapat pembentukan kata melalui proses reduplikasi. Chandra (2014:20) mengatakan di dalam bahasa Mandarin terdapat beberapa jenis kata yang terjadi reduplikasi atau pengulangan seperti kata benda (名词重叠 míngcí chóngdié), kata bantu bilangan (量词重叠 liàngá chóngdié), kata kerja (动词重叠 dòngá chóngdié) dan kata sifat (形容词重叠 xíngróngá chóngdié). Reduplikasi tersebut masing-masing memiliki polayang berbeda-beda. Dalam penelitian ini, penulis hanya memfokuskan pada reduplikasi kata kerja.

\section{TEORI DAN METODE}

\section{Landasan Teori}

Sebuah penelitian memerlukan landasan teori yang sesuai dengan masalah penelitiannya. Pada penelitian ini, penulis memakai teori morfologi struktural oleh Ramlan sebagai alat untuk menganalisis data yang ada. Morfologi struktural merupakan salah satu cabang linguistik yang mengkaji struktur dan proses pembentukan kata.

Menurut Ramlan (1965:16) dalam bukunya M orfologi Suatu Tinjauan Deskriptif menyatakan morfologi merupakan ilmu yang mempelajari seluk-beluk bentuk kata serta pengaruh perubahan-perubahan bentuk kata terhadap golongan dan arti kata, atau dengan kata lain dapat dikatakan bahwa morfologi mempelajari seluk-beluk bentuk kata sertafungsi perubahanperubahan bentuk kata itu, baik fungsi gramatik maupun fungsi semantik. Proses morfologi pada dasarnya adalah proses pembentukan kata dari sebuah bentuk dasar melalui pembubuhan afiks (dalam proses afiksasi). Ramlan (1965:47) menyatakan proses pembubuhan afiks ialah pembubuhan afiks pada sesuatu satuan, baik itu berupa bentuk tunggal maupun bentuk komplek, untuk membentuk kata. Morfologi adalah ilmu yang mempelajari selukbeluk kata, yaitu cabang ilmu yang mempelajari morfem, dan kata imbuhan (afiks) selalu berupa morfem terikat. Penulis menggunakan teori yang di kemukan oleh Ramlan, karena penulis beranggapan bahwa teori tersebut sama dengan penggunaan kata imbuhan pada data yang akan penulis teliti.

\section{D efenisi Reduplikasi}

Reduplikasi termasuk dalam kajian morfologi, karena reduplikasi memiliki status yang sama dengan proses pembentukan kata dalam morfologi. Reduplikasi merupakan perulangan kata untuk memperoleh makna atau bentuk yang berbeda. Proses reduplikasi atau pengulangan kata adalah proses morfemis yang mengulangi bentuk dasar atau bagian yang mengulangi bentuk dasar tersebut.

Ramlan (1965:38) mengatakan kata ulang atau reduplikasi adalah proses pengulangan satuan gramatik baik seluruhnya atau sebagian, baik dengan variasi fonem maupun tidak. Hasil pengulangan itu disebut kata ulang, sedangkan satuan yang diulang merupakan bentuk dasarnya.

Menurut Ramlan (1965:41) mengatakan proses pengulangan baik yang penuh maupun sebagian ada yang berfungsi mengubah goIongan kata ada pula yang tidak, seperti dalam bahasa Indonesia karang-mengarang yang berfungsi sebagai pembentuk kata nominal dari kata kerja. Seperti pada kata ulang secepatcepatnya yang berfungsi sebagai keterangan dari kata sifat. Dalam bahasa Indonesia kata ulang juga mengalami perubahan makna dari kata dasarnya seperti pada kata kehijau-hijauan yang menyatakan makna agak/menyerupai; pada kata ulang rumah-rumah yang menyatakan makna banyak.

Reduplikasi atau kata ulang adalah proses pengulangan kata, baik secara utuh maupun secara sebahagian, baik bervariasi fonem mau- 
pun tidak, baik berkombinasi dengan afiksmaupun tidak dan menjadi satuan bahasa sebagai alat fonologis dan gramatikal serta merupakan kajian dari morfologi. Pada bahasa Indonesia dikenal adanya pembentukan kata melalui proses reduplikasi. Contoh proses reduplikasi pada pengulangan seluruh bentuk dasar tanpa afiks, yaitu: rumah menjadi rumah-rumah. Reduplikasi seluruh bentuk dasar dengan afiks, yaitu: reduplikasi prefiks \{me-\}padakata "nari" menjadi kata "menari-nari", reduplikasi dengan simulfiks \{me+kan\}pada kata "lambai" menjadi kata "melambai-lambaikan", reduplikasi de ngan sufiks \{an\} pada kata "rumah" menjadi kata "rumah-rumahan" dan reduplikasi de ngan infiks \{-em\} pada kata "guruh" menjadi kata "guruh-gemuruh".

Pada bahasa Mandarin juga terdapat pembentukan kata melalui proses reduplikasi. Salah satu jenis kata yang mengalami reduplikasi adalah kata kerja. Berikut contoh reduplikasi kata kerja dalam bahasa Mandarin.

$\begin{array}{ll}\text { 问问 /wèn wèn/ } & \text { 'bertanya' } \\ \text { 问wèn + 问wèn } & \text { '问问wènwèn' } \\ \text { kata kerja + kata kerja } & \text { 'pola AA' }\end{array}$

问问 wènwèn' adalah pengulangan yang terbentuk dari kata kerja “问wèn” yang artinya 'bertanya', yang mengalami pengulangan seluruh atau pengulangan morfem asal dari pola A menjadi pola AA. Terdiri dari dua buah morfem bebas yaitu: “问wèn + 问wèn” yang berfungsi sebagai pembentuk kata ulang yang menyatakan suatu tindakan coba-coba, yaitu 'mencoba bertanya'.

\section{Metode Penelitian}

Djajasudarma (1993:31) mengatakan metode penelitian adalah salah satu hal yang sangat penting dalam sebuah penelitian atau studi ilmiah. Metode merupakan cara kerja yang bersistem dalam pelaksanaan suatu ke giatan untuk mempermudah mencapai tujuan penelitian. Sedangkan metode penelitian adalah semua asa, peraturan dan teknik-teknik yang perlu diperhatikandalam usaha dalam pengumpulan data dan dianalisis.

Dalam penelitian ini metode yang digunakan ialah metode penelitian kualitatif yang bersifat deskriptif yaitu metodeyang bertujuan membuat deskripsi, maksudnya membuat gambaran, lukisan secara sistematis, faktual dan akurat mengenai data, sifat-sifat serta hubungan fenomena-fenomena yang diteliti (Djajasudarma 1993:8). Pengumpulan data pada penelitian ini menggunakan metode simak, yaitu dengan menyimak penggunaan bahasa (Sudaryanto, 1993: 133). Kekualitatifan penelitian ini berkaitan dengan data penelitian yang tidak berupa angka-angka, tapi berupa kata atau frasa (Sudaryanto,1993:62). Dalam penelitian ini, peneliti menyimak dengan membaca berulang-ulang penggunaan bahasa yang digunakan dalam koran Hao Bao pada tanggal 1-7 Januari 2018.

Selain metode deskriptif, metode lain yang digunakan dalam penelitian ini adalah metode penelitian kepustakaan (library research) yaitu teknik pengumpulan data dan informasi yang bersumber dari buku-buku kepustakaan yang ada kaitannya dengan kata ulang (reduplikasi) dalam buku - buku berbahasa Mandarin. Dengan menggunakan metode ini data dikumpulkan dan disajikan dalam bentuk kata-kata.

\section{HASIL DAN PEMBAHASAN}

\section{Reduplikasi Kata Kerja}

Kata kerja adalah kata yang menyatakan gerakan, perubahan keinginan, keberadaan, kemungkinan, arah, dan kepastian. Reduplikasi kata kerja biasanya menyatakan arti waktu yang singkat, jumlah yang sedikit atau mencoba. Setelah di reduplikasi, maka kalimat tersebut terdengar menjadi lebih halus, santai dan tidak formal, sehingga sering digunakan dalam bahasa lisan. Pada reduplikasi kata kerja dapat juga diberi infiks $\{-\}$ (yî) sehingga prosesnya disebut proses reduplikasi berinfiks. Pada pengulangan kata kerja terdapat kata kerja terdapat 
kata kerja yang monosilabel (satu suku kata) dan dislabik (dua suku kata).

\section{Pengulangan Kata Kerja M onosilabel}

Pengulangan kata kerja monosilabel adalah pengulangan kata kerja pada satu suku kata.

Tabel 1. Pengulangan Kata Kerja M onosilabel看

\begin{tabular}{|c|c|c|c|}
\hline 老师 & 看 & 看 & 你们 \\
\hline lăo shī & kàn & kàn & nǐ men \\
\hline Guru & lihat & lihat & mereka \\
\hline \multicolumn{3}{|c|}{ Guru melihat-lihat mereka } \\
\hline
\end{tabular}

Kata yang dihitamkan pada contoh tabel (1) diatas adalah 看 kàn yang artinya 'melihat'. Contoh tersebut merupakan atribut yang menerangkan sifat kata kerja monosilabel, kemudian kata 看 kàn direduplikasikan menjadi kata 看看 kànkàn yang artinya 'melihat-lihat' yang berfungsi sebagai pembentuk kata ulang yang menyatakan waktu suatu tindakan sangat pendek. Dalam kalimat ini kata tersebut berfungsi sebagai kata kerja yang menerangkan sebagai predikat dan memiliki pola AA.

Tabel 2. Pengulangan K ata Kerja M onosilabel 尝

\begin{tabular}{|c|c|c|c|c|c|c|}
\hline 我 & 尝 & 尝 & 妈妈 & 做 & 的 & 菜 \\
\hline wǒ & cháng & cháng & māmā & zuò & de & cài \\
\hline saya & coba & coba & Ibu & melakukan & partikel & sayur \\
\hline
\end{tabular}

Saya mencoba-coba/ merasa-rasa masakan Ibu.

Kata yang dihitamkan pada contoh tabel (2) diatas adalah 尝 cháng yang artinya 'rasa'. Contoh tersebut atribut yang menerangkan sifat kata kerja monosilabel, kemudian kata 尝 cháng direduplikasikan menjadi kata 尝尝 chángcháng yang artinya 'merasa-rasa' yang berfungsi sebagai pembentuk kata ulang yang menyatakan waktu suatu tindakan sangat pendek. Dalam kalimat ini kata tersebut berfungsi sebagai kata kerja yang menerangkan sebagai predikat dan memiliki pola AA.
Tabel 3. Pengulangan Kata Kerja M onosilabel 听

\begin{tabular}{|c|c|c|c|c|}
\hline 听 & 听 & 爸爸 & 的 & 建议 \\
\hline Tīng & tīng & bàba & de & jiànyì \\
\hline dengar & dengar & Ayah & partikel & saran \\
\hline \multicolumn{5}{|c|}{ Mendengar saran Ayah. } \\
\hline
\end{tabular}

Kata yang dihitamkan pada contoh tabel (3) diatas adalah 听 tîng yang artinya 'dengar'. Contoh tersebut menunjukan atribut yang menerangkan sifat kata kerja monosilabel, kemudian kata 听 tîng direduplikasikan menjadi kata 听听 tîngtîng yang artinya 'mendengar' yang berfungsi sebagai pembentuk kata ulang yang menyatakan waktu suatu tindakan sangat pendek. Dalam kalimat ini kata tersebut berfungsi sebagai kata kerja yang menerangkan kata sifat monosilabel 8r8rbàba 'ayah' dan memiliki pola AA.

Tabel 4. Pengulangan Kata Kerja M onosilabel 帮

\begin{tabular}{|c|c|c|c|c|c|c|}
\hline 帮 & 帮 & 我 & 这 & 可怜 & 的 & 人 \\
\hline Bāng & bāng & wǒ & zhè & kělián & de & rén \\
\hline bantu & bantu & saya & ini & kasihan & partikel & orang \\
\hline \multicolumn{6}{|c|}{ Bantu-bantu saya yang kasihan ini. } \\
\hline
\end{tabular}

Kata yang dihitamkan pada contoh tabel (4) diatas adalah 帮 bâng yang artinya 'bantu'. Contoh tersebut atribut yang menerangkan sifat kata kerja monosilabel, kemudian kata 帮 bâng direduplikasikan menjadi kata 帮帮 bângbâng yang artinya 'membantu' yang berfungsi sebagai pembentuk kata ulang yang menyatakan waktu suatu tindakan sangat pendek. Dalam kalimat ini kata tersebut berfungsi sebagai kata kerja yang menerangkan kata sifat monosilabelï 可怜 kilián 'kasihan' dan memiliki pola AA.

Tabel 5. Pengulangan Kata Kerja M onosilabel 招

\begin{tabular}{|c|c|c|c|c|c|c|c|}
\hline 他 & 远远 & 的 & 向 & 我 & 招 & 招 & 手 \\
\hline tā & yuănyuăn & de & xiàng & wǒ & zhāo & zhāo & Shǒu \\
\hline dia & jauh & partikel & arah & saya & lambai & lambai & tangan \\
\hline \multicolumn{7}{|l|}{ Dari arah yang jauh dia melambai-lambaikan tangan ke arah saya. } \\
\hline
\end{tabular}


Kata yang dihitamkan pada contoh nomor (5) diatas adalah 招 zhâo yang artinya 'lambai'. Contoh tersebut merupakan atribut yang menerangkan sifat kata kerja monosilabel, kemudian kata 招 zhâo direduplikasikan menjadi kata 招招 zhâo zhâo yang artinya 'melambai-lambaikan' yang berfungsi sebagai pembentuk kata ulang yang menyatakan waktu suatu tindakan sangat pendek. Dalam kalimat ini kata tersebut berfungsi sebagai kata kerja yang menerangkan kata nomina (kata benda) monosilabel 手 shòu 'tangan' dan memiliki pola AA.

\section{Pengulangan Kata Kerja Berinfiks}

Pengulangan kata kerja berinfiks adalah pengulangan kata dasar/ kata tunggal yang kemudian dilanjutkan dengan infiksasi. Jadi, pada proses berinfiks ada dua proses morfologi yang terjadi, yaitu pengulangan/ reduplikasi dan infiksasi.

Tabel 6. Pengulangan Kata Kerja Berinfiks 尝一尝

\begin{tabular}{|c|c|c|c|c|c|c|c|c|c|c|}
\hline 我 & 和 & 父亲 & 一起 & 尝 & 一 & 尝 & 妈妈 & 做 & 的 & 汤圆 \\
\hline wǒ & hé & fùqīn & yīqǐ & cháng & ȳi & cháng & māmā & zuò & de & tāngyuán \\
\hline saya & dan & ayah & bersama & rasa & satu & rasa & ibu & memasak & partikel & mochi \\
\hline \multicolumn{8}{|c|}{ Saya dan ayah bersama-sama mencoba masakan mochi ibu. } \\
\hline
\end{tabular}

Kata yang dihitamkan pada contoh tabel ulang berinfiks. Kataulang berinfiks ini umum(6) diatas adalah 尝 cháng yang artinya 'rasa', nya terdapat pada kata kerja monosilabel yang kemudian kata 尝 cháng direduplikasikan berfungsi sebagai pembentuk kata ulang yang menjadi kata 尝一尝 cháng yî cháng yang menyatakan suatu perbuatan yang tidak serius. artinya ‘merasa-rasa'. Contoh tersebutmerupa- Dalam kalimat ini kata tersebut berfungsi kan atribut yang menerangkan sifat kata kerja sebagai predikat dan memiliki pola ANA. monosilabel, dengan sisipan — yî yaitu kata

\section{Tabel 7. Pengulangan Kata Kerja}

Berinfiks 问一问

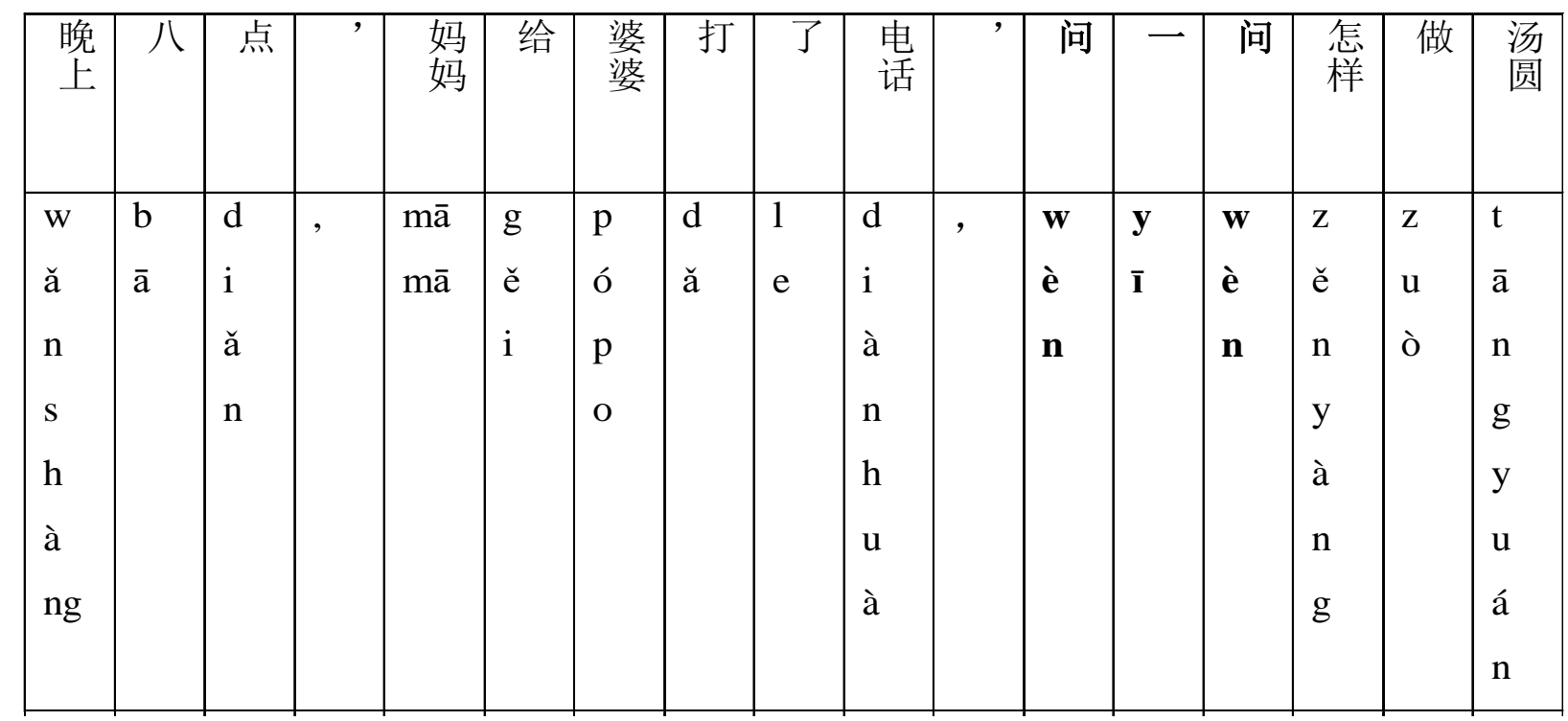




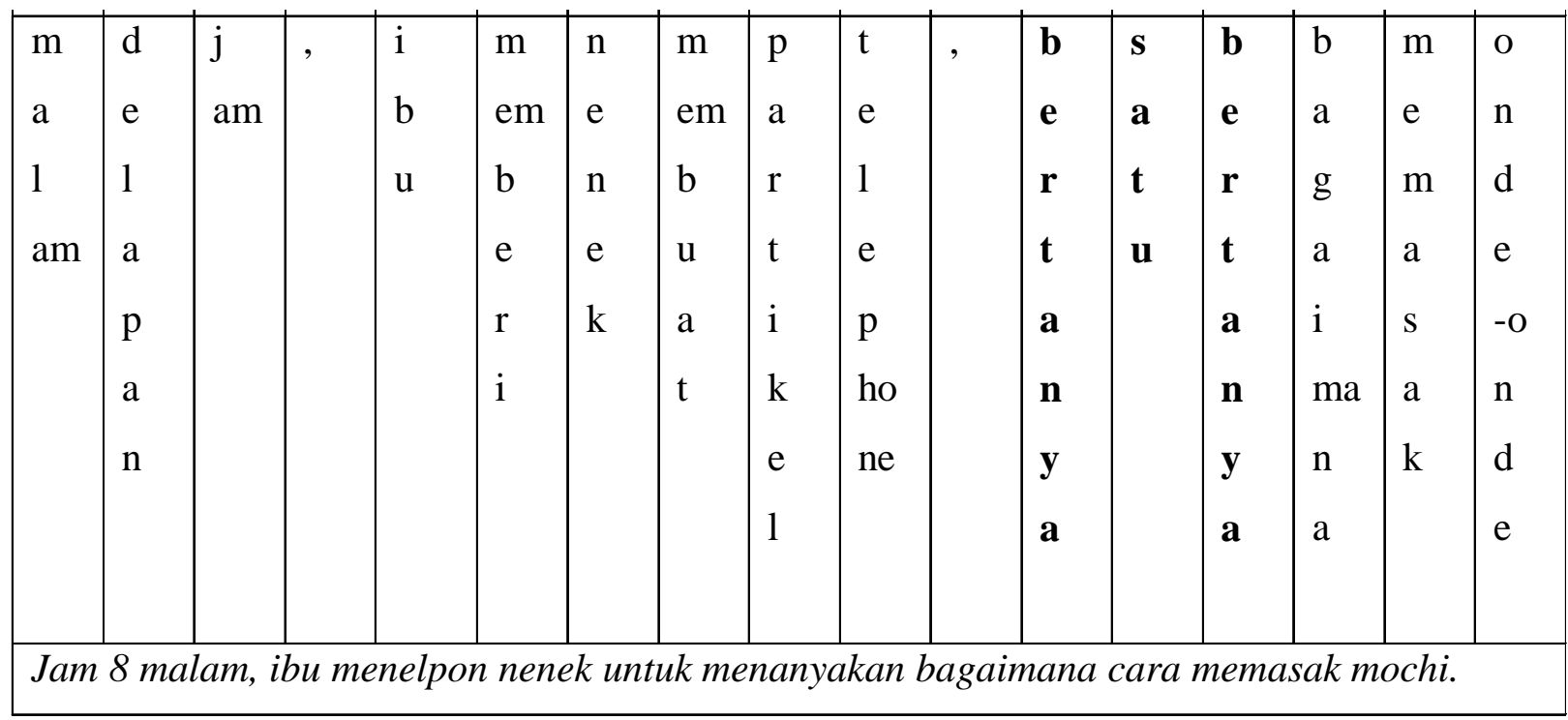

Kata yang dihitamkan pada contoh tabel (7) diatas adalah 问 wèn yang artinya 'tanya', kemudian kata 问 wèn direduplikasikan menjadi kata 问一问 wènyîwèn yang artinya 'bertanya-tanya'. Contoh tersebut merupakan atribut yang menerangkan sifat kata kerja mono- silabel, dengan sisipan - yî yaitu kata ulang berinfiks. Kata ulang berinfiks ini umumnya terdapat pada kata kerja monosilabel berfungsi sebagai pembentuk kata ulang yang menyatakan suatu perbuatan yang tidak serius. Dalam kalimat ini kata tersebut berfungsi sebagai pre dikat dan memiliki pola ANA.

Tabel 8. Pengulangan Kata Kerja Berinfiks 听一听

\begin{tabular}{|c|c|c|c|c|c|c|c|c|c|c|c|}
\hline 你 & 听 & 一 & 听 &, & 是 & 不 & 是 & 有 & 人 & 在 & 唱歌 \\
\hline nǐ & tīng & $\mathbf{y} \overline{\mathbf{i}}$ & tīng &, & shiì & bù & shì & yǒu & rén & zài & chànggē \\
\hline kamu & dengar & dengar & satu &, & adalah & tidak & adalah & ada & orang & di & menyanyi \\
\hline \multicolumn{8}{|c|}{ Kamu dengar, apakah ada orang yang menyanyi? } \\
\hline
\end{tabular}

Kata yang dihitamkan pada contoh tabel (8) diatas adalah 听 tîng yang artinya 'dengar', kemudian kata 听 tîng direduplikasikan menjadi kata 听一听 tîngyîtîng yang artinya 'mendengar-dengar. Contoh tersebut merupakan atribut yang menerangkan sifat kata kerja monosilabel, dengan sisipan — yî yaitu kata ulang berinfiks. Kata ulang berinfiks ini umumnya terdapat pada kata kerja monosilabel berfungsi sebagai pembentuk kata ulang yang menyatakan suatu perbuatan yang tidak serius. Dalam kalimat ini kata tersebut berfungsi se bagai predikat dan memiliki pola ANA. 
Tabel 9. Pengulangan Kata Kerja

Berinfiks 看一看

\begin{tabular}{|c|c|c|c|c|c|c|c|c|c|c|c|c|}
\hline 我 & 还 & 想 & 去 & 黄射 & 伙计 & 过 & 日子 & 的 & 地方 & 看 & 看 \\
\hline wǒ & hái & xiăng & qù & huángshè & huǒ jì & guò & rìzi & de & dìfāng & kàn & ȳ & kàn \\
\hline saya & masih & ingin & pergi & huangshe & teman & melewati & hari & partikel & tempat & mellihat & satu & melihat \\
& & & & & & & & & & & & \\
\hline
\end{tabular}

Kata yang dihitamkan pada contoh tabel (9) diatas adalah 看 kàn yang artinya 'lihat', kemudian kata 看 kàn direduplikasikan menjadi kata 看一看 kànyîkàn yang artinya 'melihatlihat. Contoh tersebut merupakan atribut yang menerangkan sifat kata kerja monosilabel, dengan sisipan - yî yaitu kata ulang berinfiks. Kata ulang berinfiks ini umumnya terdapat pada kata kerja monosilabel berfungsi sebagai pembentuk kata ulang yang menyatakan suatu perbuatan yang tidak serius. Dalam kalimat ini kata tersebut berfungsi sebagai predikat dan memiliki pola ANA.

\section{Pengulangan Kata Kerja D islabik}

Pengulangan kata kerja dislabik adalah pengulangan kata kerja pada dua suku kata

Tabel 10. Pengulangan Kata Kerja D islabik 休息

\begin{tabular}{|c|c|c|c|c|c|c|c|c|c|c|}
\hline 他 & 累 & 了 &, & 让 & 他 & 休 & 息 & 休 & 息 & 吧 \\
\hline tā & lèi & le &, & ràng & tā & Xiū & xi & xiū & xi & ba \\
\hline dia & lelah & partikel &, & mengajak & dia & Istirahat & nafas & istirahat & nafas & partikel \\
& & & & & & & & & & \\
\hline
\end{tabular}


Kata yang dihitamkan pada tabel (10) yang berfungsi sebagai pembentuk kata ulang diatas adalah 休息 xiûxi yang artinya 'istirahat'. yang menyatakan waktu suatu tindakan Contoh tersebut merupakan atribut yang sangat pendek. Dalam kalimat ini kata tersebut menerangkan kata kerja dislabik, kemudian berfungsi sebagai katakerjayang menerangkan kata 休息 xiûxi direduplikasikan menjadi kata sebagai predikat dan memiliki pola ABAB. 休息休息 xiûxixiûxi yang artinya 'beristirahat'

Tabel 11. Pengulangan Kata Kerja D islabik 考虑

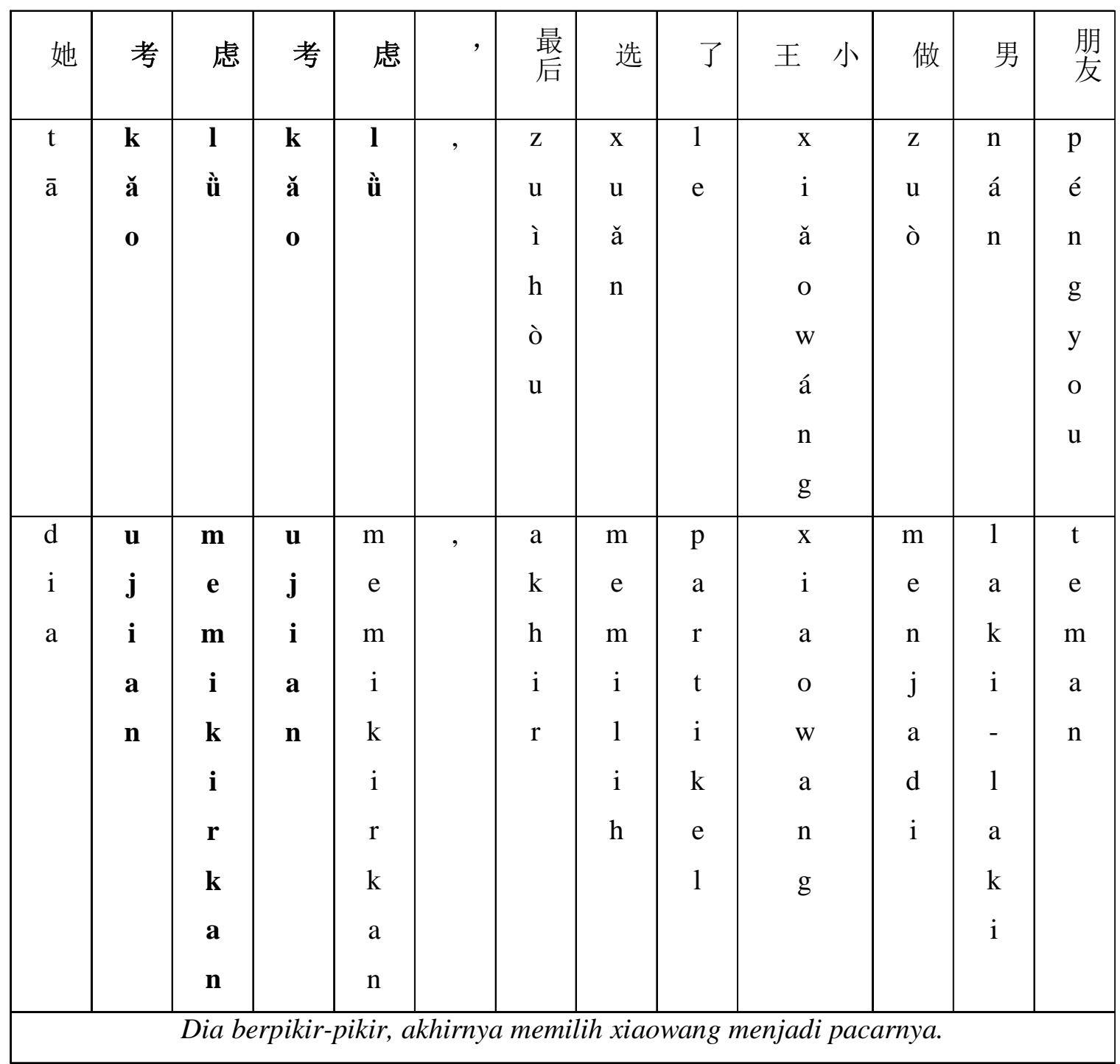

Kata yang dihitamkan pada contoh nomor (11) diatas adalah 考虑 kăolù yang artinya 'berpikir'. Contoh tersebut merupakan atribut yang menerangkan kata kerja dislabik, kemudian kata 考虑 kăolù direduplikasikan menjadi kata 考虑考虑 kăolùkăolù yang artinya 'berpikir-pikir' yang berfungsi sebagai pembentuk kata ulang yang menyatakan waktu suatu tindakan sangat pendek. Dalam kalimat ini kata tersebut berfungsi sebagai kata kerja yang menerangkan sebagai predikat dan memiliki pola ABAB. 


\section{PENUTUP}

\section{Simpulan}

Berdasarkan hasil dan pembahasan yang telah diuraikan, dapat ditarik kesimpulan bahwa pada reduplikasi kata kerja terdapat pengulangan seluruh dan ada juga yang mengalami pengulangan yang berkombinasi dengan afiks.

Pola reduplikasi kata kerjayaitu pengulangan kata kerja monosilabel memiliki pola AA, pengulangan kata kerja berinfiks memiliki pola ANA dan pengulangan kata kerja dislabik memiliki pola ABAB

\section{Saran}

Reduplikasi (kata ulang) dalam penelitian ini hanya dibatasi pada reduplikasi kata kerja, masih banyak masalah lainnya yang belum disentuh dan diketahui oleh penulis, misalnya bentuk dan proses pada reduplikasi. Oleh karenanya, penelitian seperti ini perlu dilakukan pada kesempatan berikutnya. Penulis menyadari bahwa tulisan ini belum bisa dikatakan sebagai penelitian yang sempurna. Berbagai kritik dan saran yang bersifat konstruktif sangat diharapkan demi perbaikan tulisan ini.

\section{DAFTAR PUSTAKA}

Chandra, Yulie Neila. 2014. M orfologi Bahasa $M$ an darin. Jakarta: Mitra Wacana Media.

Djadjasudarma, Fatimah. 1993. M etode Linguistik. Bandung: Anggota IKAPI

Keraf, Gorys. 2001. Tata Bahasa Indonesia. Jakarta: Nusa Indah

Ramlan. 1965. M orfologi Suatu Tinjauan Deskriptif. Yogyakarta: UP. Karyono

Sudaryanto. 1993. M etode dan A neka Teknik A nalisis Bahasa. Yogyakarta: Duta Wacana University Press

Verhaar. 2008. A sas-A sas Linguistik U mum. Yogyakarta: Gajah Mada University Press.

Yongxin, Zhao. 2005. Intisari Tata Bahasa $M$ andarin. Bandung: Rekaya Sains. 